\title{
PERSEPSI PENGELOLA PROGRAM PNFI TERHADAP TUGAS POKOK PENILIK PNFI DI KABUPATEN CIREBON
}

\author{
${ }^{1}$ Ahmad Hamdan, ${ }^{2}$ Nunu Heryanto, ${ }^{3}$ Jajat S. Ardiwinata \\ ${ }^{1}$ Universitas Siliwangi, ${ }^{2}$ Universitas Pendidikan Indonesia, ${ }^{3}$ Universitas Pendidikan Indonesia \\ ahmad.hamdan@unsil.ac.id
}

\begin{abstract}
ABSTRAK
Permasalahan yang terjadi di Kabupaten Cirebon wilayah timur yaitu penilik yang belum secara maksimal menjalankan tugas pokoknya sesuai Permenpan No 14 Tahun 2010. Tujuan penelitian ini adalah untuk mendeskripsikan peran penilik dalam menjalankan tugas pokok dan mendeskripsikan manfaat yang dirasakan oleh para pengelola program PNFI terhadap keberadaan penilik. Metode penelitian yang digunakan dalam penelitian ini yaitu deskiptif kualitatitf. Teknik pengumpulan data yang digunakan yaitu wawancara, observasi dan studi kepustakaan. Populasi dalam penelitian ini yaitu para penilik dan pengelola program PNFI di Kabupaten Cirebon wilayah Timur. Hasil yang didapat dari penelitian ini yaitu penilik sebagai pengendali program dan evaluasi dampak program PNFI sudah berjalan sebagaimana mestinya, meskipun masih ada beberapa penilik yang melaksanakan tugasnya tidak maksimal dan pembagian tugas penilik belum berjalan sesuai dengan peraturan yang ada. Para pengelola program sangat merasakan keberadaan penilik dalam meningkatkan mutu program PNFI.
\end{abstract}

Kata kunci: Penilik, Pendidikan nonformal, pendidikan informal

\begin{abstract}
The problems that occur in Cirebon Regency in the eastern region are the overseers who have not optimally carried out their main tasks in accordance with Permenpan No. 14 of 2010. The purpose of this study is to describe the role of inspectors in carrying out the main tasks and describe the benefits felt by the managers of the PNFI program for the existence of inspectors. The research method used in this research is descriptive qualitative. Data collection techniques used were interviews, observation and literature study. The population in this study is the inspectors and managers of the PNFI program in Cirebon Regency in the East. The results obtained from this study are the inspectors as program controllers and the impact evaluation of the PNFI program has been running properly, although there are still some inspectors who carry out their duties are not optimal and the division of inspector duties has not run according to existing regulations. Program managers really feel the presence of inspectors in improving the quality of the PNFI program.
\end{abstract}

Keywords: Inspectors, Nonformal Education, Informal Education 


\section{PENDAHULUAN}

Sumber daya manusia merupakan motor penggerak yang begitu penting dalam proses pembangunan masyarakat dan juga pembangunan sumber daya lainnya. Kualitas sumber daya manusia dapat menjadi titik tolak berhasil tidkanya proses transfer ilmu pengetahuan dan teknologi dan juga sebagai sumber informasi dan komunikator di jaman yang serba cepat ini. Pembangunan kualitas sumber daya manusia yang bermutu perlu dilakukan secara berkesinambungan dan lestari, sehingga mampu menjadi modal dasar pembangunan yang dapat dikembangkan secara optimal dan dapat meningkatkan produktifitas kerjanya.

Salah satu bentuk peningkatan kualitas sumber daya manusia yaitu dengan pendidikan, sebagai proses transfer of knowledge agar manusia memiliki banyak sumber pengetahuan dan dapat mengembangkan potensi yang dimiliki oleh setiap individu. pendidikan menurut Undang-undang No 20 Tahun 2003 adalah usaha sadar dan terencana untuk mewujudkan suasana belajar dan proses pembelajaran agar peserta didik secara aktif mengembangkan potensi dirinya untk memiliki kekuatan spiritual keagamaan, pengendalian diri, kepribadian, kecerdasan akhlak muliah serta keterampilan yang diperlukan dirinya, masyarakat, bangsa dan negara.

Jika mengacu pada konsep pendidikan tersebut jelas bahwa pendidikan ditujukan untuk meningkatkan potensi manusia agar menjadi orang yang berbudi dan berakal, memiliki pengetahuan, pengalaman serta wawasan agar dapat bermanfaat bagi dirinya dan juga lingkungan sekitarnya. Pendidikan sebagai wadah untuk meningkatkan kualitas sumber daya manusia tentunya dibutuhkan pula orang-orang yang berkualitas didalamnya agar output yang diharapkan juga menjadi maksimal.

Pendidikan membutuhkan tenaga pendidik dan kependidikan yang berkompeten dibidangnya agar menghasilkan sumber daya manusia yang berkualitas. Pendidikan menurut Undang-undang nomor 20 Tahun 2003 memiliki 3 jalur, yaitu formal, nonformal dan informal. Untuk mendukung keberhasilan suatu program pendidikan baik formal ataupun nonformal tentunya memerlukan tenaga pendidik dan kependidikan yang berkompeten.

Dalam Undang-undang No 20 Tahun 2003 tentang Sisdiknas dijelaskan bahwa pendidik adalah tenaga kependidikan yang berkualifikasi sebagai guru, dosen, konselor, pamong belajar, widyaiswara, tutor, instruktur, fasilitator, dan sebutan lain yang sesuai kekhususannya, serta berpartisipasi dalam menyelenggarakan pendidikan. Sedangkan pengertian tenaga kependidikan adalah anggota masyarakat yang mengabdikan diri dan diangkat untuk menunjang penyelenggaraan pendidikan. Yang termasuk tenaga kependidikan dalam pasal 39 ayat 1 meliputi pengelola satuan pendidikan, penilik, pamong belajar, pengawas, peneliti, pengembang, pustakawan, laboran dan teknisi sumber belajar.

Penilik merupakan orang yang berhadapan langsung dengan kelompok sasaran selain pengelola program Pendidikan Nonformal. Penilik adalah salah satu tenaga kependidikan nonformal yang bertugas di lapangan untuk memberikan bimbingan, arahan bantuan dan evaluasi kepada para pelaksana program dalam kelembagaan pendidikan nonformal agar sesuai dengan yang diharapkan. Satuan pendidikan nonformal terdiri atas lembaga kursus, lembaga pelatihan, kelompok belajar, pusat kegiatan belajar masyarakat, dan majelis taklim, serta satuan pendidikan yang sejenis.

Menurut rahmat (2011) penilik harus mampu memotivasi, mendorong, menggalang, mengarahkan, membimbing, dan mensupervisi seluruh pendidik dan tenaga kependidikan yang menjadi tanggung jawabnya. Melihat perannya yang cukup strategis, diharapkan penilik dapat meningkatkan proses pembelajaran sehingga proses pendidikan nonformal dapat berjalan lebih efektif. Penilik sebagai petugas lapangan ternyata selain orang yang secara langsung berhubungan dengan sasaran program Pendidikan Luar Sekolah, juga sebagai penentu dalam mengimplementasikan dan memadukan keseluruhan program PNFI baik secara horizontal maupun vertikal. Di sisi lain mereka juga menjadi penyeimbang antara program yang datang dari atas dengan tuntutan kebutuhan yang ada di masyarakat itu sendiri. Kedudukan, tugas pokok dan fungsi penilik diatur dalam Permenpan nomo 14 Tahun 2010 
tentang Jabatan Fungsional Penilik dan Angka Kreditnya yaitu melaksanakan kegiatan pengendalian mutu dan evaluasi dampak program PNFI.

\section{KAJIAN TEORI}

\section{Persepsi}

Persepsi (perception) menurut Leavitt (1978) dalam Sobur (2003: 445) dalam arti sempit ialah penglihatan, bagaimana cara seseorang melihat sesuatu; sedangkan dalam arti luas adalah pandangan atau pengertian, yaitu bagaimana seseorang memandang atau mengartikan sesuatu. Persepsi merupakan bagian dari keseluruhan proses yang menghasilkan tanggapan setelah rangsangan diterapkan kepada manusia. Seperti yang ada dalam bagan berikut mengenai proses terjadinya persepsi dan kognisi diperlukan dalam semua kegiatan psikologis, diperlukan bagi orang yang paling sedikit terpengaruh atau sadar akan adanya rangsangan menerima dan dengan suatu cara menahan dampak dari rangsangan.

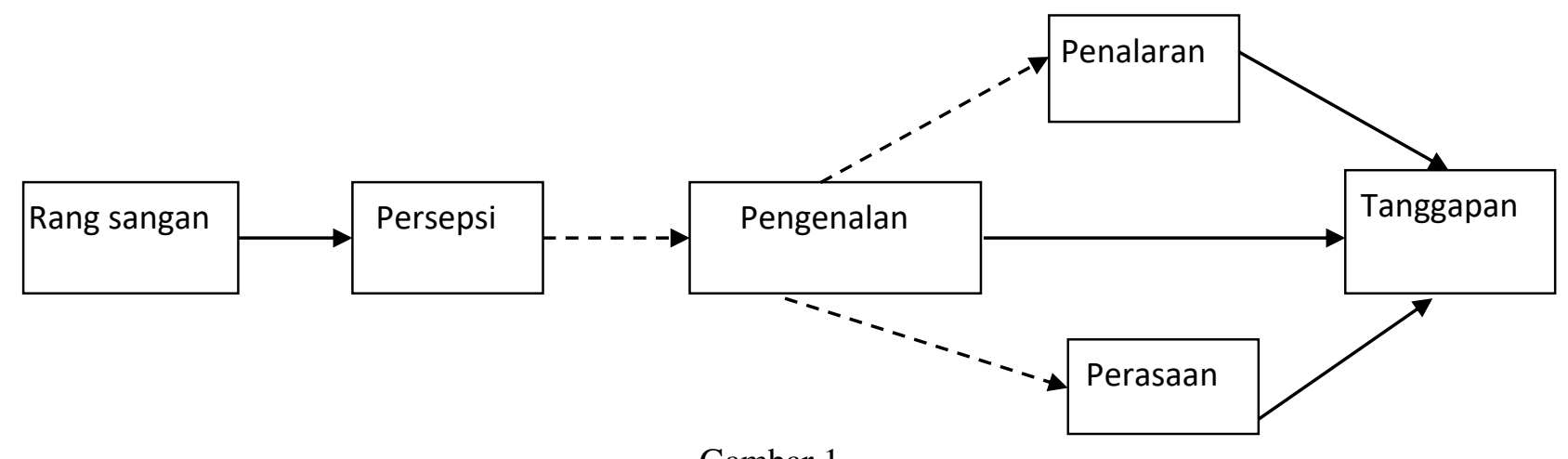

Gambar 1

Variabel Psikologis diantara Rangsangan dan Tanggapan

Berdasarkan pemikiran atau penjelasan tentang konsepsi dari persepsi, dapat disimpulkan bahwa persepsi adalah suatu proses pemberian makna yang dilakukan secara sadar berupa tanggapan atau pendapat seseorang terhadap suatu objek atau peristiwa yang diterima melalui alat inderanya, dalam hal ini tanggapan, pendapat, penilaian dan harapan para pelaksana program terhadap pelaksanaan tugas pokok penilik PNFI.

\section{Ketenagaan PNFI}

Pendidikan nonformal sebagaimana dinyatakan dalam Undang-undang Nomor 20 Tahun 2003 tentang sistem Pendidikan Nasional pasa 36 ayat 1 merupakan bagian dari sistem pendidikan nasional, yang merupakan jalur pendidikan di luar pendidikan formal yang dapat dilaksanakan secara terstruktur dan berjenjang yang diselenggarakan bagi warga masyarakat yang memerlukan layanan pendidikan yang berfungsi sebagai pengganti, penambah, dan/atau pelengkap pendidikan nonformal dalam rangka mendukung pendidikan sepanjang hayat.

Pendidik dan tenaga kependidikan adalah dua profesi yang sangat berkaitan erat dengan dunia pendidikan, sekalipun lingkup keduanya berbeda. Dalam UU Sisdiknas no 20 Tahun 2003, terminologi pendidik mencakup guru, dosen, konselor, pamong belajar, pamong, widyaiswara, tutor, instruktur, fasilitator, dan sebutan lain yang sesuai dengan kekhususannya serta berpartisipasi dalam menyelenggarakan pendidikan yang berfungsi sebagai agen pembelajar para warga belajar. Dalam konteks PNF, pendidik PNF merupakan anggota masyarakat yang memiliki tugas dan kewenangan 
dalam merencanakan dan melaksanakan proses, serta menilai hasil, melakukan pembimbingan dan pelatihan pada satuan PNF.

Sedangkan tenaga kependidikan lebih luas dimensi dan spektrumnya. Pada konteks PNF, tenaga kependidikan merupakan anggota masyarakat yang mengabdikan diri dan diangkat untuk menunjang penyelenggaraan satuan PNF. Tenaga kependidikan bertugas melaksanakan administrasi pengelolaan, pengembangan, pengawasan, dan pelayanan teknis untuk menunjang proses pendidikan pada satuan PNF.

Secara umum tenaga kependidikan menurut UU Sisdiknas No 20 Tahun 2003 mencakup pemimpin satuan pendidikan, penilik, tenaga perpustakaan, tenaga laboratorium, teknisi sumber belajar, tenaga lapangan pendidikan, tenaga administrasi, psikolog, pekerja sosial, terapis, tenaga kebersihan, dan sebutan lain untuk petugas sejenis yang bekerja pada satuan pendidikan.

Penilik menurut Sappaile (2007) adalah PNS yang diberi tanggung jawab, wewenang, dan hak secara penuh oleh pejabat yang berwenang untuk melakukan kegiatan penilikan pendidikan luar sekolah yang meliputi pendidikan masyarakat, kepemudaan, pendidikan anak usia dini dan keolahragaan. Penilik menurut Permen No 14 Tahun 2010 adalah tenaga kependidikan dengan tugas utama melakukan kegiatan pengendalian mutu dan evaluasi dampak program pendidikan anak usia dini (PAUD), pendidikan kesetaraan dan keaksaraan, serta kursus pada jalur Pendidikan Nonformal dan Informal (PNFI).

Menurut Sihombing (Kartiwa, 2005) menjadi penilik PNFI sangat berbeda dengan petugas kependidikan pada umumnya. Untuk mampu menjalankan tugasnya dengan baik, seorang penilik harus memilik hal-hal yang berkaitan dengan dunia pendidikan masyarakat, antara lain: mengerti nilai-nilai budaya yang ada pada masyarakat binaan, mempunyai jiwa kepemimpinan, seperti yang diungkapkan oleh Ki hajar Dewantara 'ing ngarso sung tulodo, ing madyo mangun karso, tut wuri handayani” yang berarti jiwa rela berkorban, mempunyai pengetahuan dan pengalaman dan menilai kebutuhan pasar (market need) yang kemudian menterjemahkannya kedalam "learning need" dari warga belajar, mampu menggali potensi, menumbuhkan/mengembangkan serta memanfaatkan seluruh potensi yang ada di masyarakat, termasuk memilih menggali tenaga Kependidikan nonformal, mampu memotivasi warga belajar dan masyarakat umum untuk ikut berpartisipasi aktif dalam penyelenggaraan pendidikan bagi masyarakat, memiliki kreativitas, dinamika, serta selalu berfikir inovatif, mempunyai kemampuan untuk memilih dan mendahulukan yang utama dan mendesak.

Sebagai seorang penilik yang mempunyai tugas sebagai pengendali mutu dan evaluasi dampak tentunya harus mempunyai keahlian sebagai pelaksana supervisi, monitoring dan evaluasi. Tugas pokok dari seorang penilik menurut Permenpan No 14 Tahun 2010 pasal 4 adalah melaksanakan kegiatan pengendalian mutu dan evaluasi dampak program PNFI. Dari pernyataan tersebut kemudian dijabarkan pada pasal 7 mengenai kegiatan pengendalian mutu program PNFI, meliputi (a) perencanaan program pengendalian mutu PNFI; (b) pelaksanaan pemantauan program PNFI; (c) pelaksanaan penilaian PNFI; (d) pelaksanaan pembimbingan dan pembinaan kepada pendidik dan tenaga kependidikan satuan PNFI; dan (e) penyusunan laporan hasil pengendalian mutu PNFI.

\section{Pengendalian Mutu Program}

Mutu pendidikan menurut Suryadi (2009; 7) adalah kemampuan suatu satuan pendidikan dalam mendayagunakan sumber-sumber daya pendidikan secara efisien dalam rangka meningkatkan kemampuan belajar peserta didik seoptimal mungkin. Pengendalian mutu program pendidikan nonformal adalah proses memonitor melalui penilaian dan perbaikan agar hasilnya melebihi harapan dan memuaskan pelanggan khususnya dalam bidang pendidikan nonformal, dalam hal ini kegiatan 
pengendalian mutu program yang dilakukan oleh penilik PNFI dimaksudkan agar program-program yang dilakukan oleh lembaga pendidikan nonformal sesuai dengan standar nasional pendidikan sebagaimana diamanatkan dalam Undang-undang tentang Standar Nasional Pendidikan, termasuk didalamnya standar pendidikan nonformal.

Manfaat dari pengendalian mutu program yaitu bermanfaat untuk mencegah terjadinya kesalahan dalam produksi dengan cara mengusahakan setiap langkah yang dilaksanakan, setiap sumberdaya yang digunakan dan setiap aspek yang terlibat dalam proses produksi dievaluasi secara terus menerus untuk mencegah terjadinya kesalahan atau kekeliruan.

Agar dalam pelaksanaan pengendalian mutu program PNFI serta evaluasi dampak program PNFI dapat dijalankan dengan baik maka seoramg penilik harus memiliki kemampuan/kompetensi, tentang bagaimana cara merencanakan program pengendalian mutu, pemantauan program, penilaian program, pelaksanaan pembimbingan dan pembinaan kepada pendidik dan tenaga kependidikan serta penyusunan laporan hasil pengendalian mutu program PNFI, juga penilik harus memiliki kemampuan terkait substansi dari program yang akan dilakukan kegiatan pengendalian mutu programnya.

4. Sasaran Program Penilikan PNFI

a. Pendidikan Anak Usia Dini (PAUD)

Pendidikan Anak Usia Dini Pendidikan Anak Usia Dini (PAUD) adalah pendidikan yang ditujukan bagi anak usia dini (0-6 tahun) yang dilakukan melalui pemberian berbagai rangsangan untuk membantu pertumbuhan dan perkembangan jasmani dan rohani agar memiliki kesiapan dalam memasuki jenjang pendidikan dalam kehidupan selanjutnya (UU No.20 Tahun 2003 tentang SISDIKNAS).

Kegiatan pendidikan anak usia dini diarahkan pada tiga peran pendidikan anak usia dini, yaitu sebagai berikut:

1) Pendidikan sebagai proses belajar dalam diri anak. Anak harus diberikan kesempatan untuk belajar secara optimal, kapan saja dan dimana saja. Implementasinya terwujud dengan memberikan kesempatan kepada anak untuk mendengar, melihat, mengamati, dan menyentuh benda-benda di sekitarnya.

2) Pendidikan sebagai proses sosialisai. Pendidikan bukan hanya untuk mencerdaskan dan membuat anak terampil, tetapi juga membuat anak menjadi manusia yang bertanggung jawab, bermoral, dan beretika. Pendidikan mempersiapkan anak untuk mampu hidup sesuai dengan kebutuhan zaman di masa depan.

3) Pendidikan sebagai proses pembentukan kerjasama peran. Dengan demikian, anak dapat mengetahui bahwa manusia adalah makhluk sosial yang saling melengkapi. Manusia membutuhkan orang lain karena secara individual mempunyai kekurangan dan di sisi lain memiliki kelebihan yang dapat memberikan nilai tambah bagi orang lain.

\section{b. Pendidikan Kesetaraan dan Keaksaraan}

Pendidikan kesetaraan merupakan sasalah satu jenis pendidikan nonformal yang berjenjang dan berstruktur yang memberikan kompetensi minimal bidang akademik dan lebih memiliki komperensi kecakapan hidup agar lulusannya mampu hidup mandiri dan belajar sepanjang hayat.

Pendidikan kesetaraan merupakan pendidikan nonformal yang mencakup program Paket A setara SD/MI, Paket B setara SMP/MTs, dan Paket C setara SMA/MA denga penekanan pada penguasaan pengetahuan, keterampilan fungsional, serta pengembangan sikap dan kepribadian profesional peserta didik. Hasil pendidikan nonformal dapat dihargai setara dengan hasil program pendidikan formal 
setelah melalui proses penilaian penyetaraan oleh lembaga yang ditunjuk oleh Pemerintah atau Pemerintah Daerah dengan mengacu pada standar nasional pendidikan (UU No. 20 Tahun 2003 Pasal 26 Ayat 6). Setiap peserta didik lulusan ujian kesetaraan Paket A, Paket B, atau Paket C mempunyai hak eligibitas yang sama dan setara dengan pemegang ijazah SD/MI, SMP/MTs dan SMA/MA untuk mendaftar pada satuan pendidikan yang lebih tinggi. Status kelulusan Paket $\mathrm{C}$ mempunyai hak eligibitas yang setara dengan pendidikan formal dalam memasuki lapangan kerja.

Keaksaraan adalah salah satu program pada jalur pendidikan nonformal dengan sasaran warga masyarakat yang tidak bisa atau belum lancar dalam membaca tulisan. Keaksaraan ini merupakan salah satu program dalam rangka pemberantasan tuna aksara, dengan sasaran sebagian besar adalah warga belajar berusia dewasa. Dalam pembelajaran keaksaraan ini tentunya tidak mudah untuk membelajarkan orang dewasa, apalagi jika tidak memiliki pengalaman dalam membelajarkan warga belajar yang berusia dewasa, sehingga dalam sistem pembelajaran keaksaraan ini menggunakan pendekatan andragogi atau sistem pembelajaran yang diperuntukan bagi orang dewasa.

\section{c. Pendidikan Kursus Pada Jalur PNFI}

Kursus dan pelatihan diselenggarakan bagi masyarakat yang memerlukan bekal pengetahuan, keterampilan, kecakapan hidup, dan sikap untuk mengembangkan diri, mengembangkan profesi, bekerja, usaha mandiri, dan/atau melanjutkan pendidikan ke jenjang yang lebih tinggi.

Kursus sebagai suatu cara pembelajaran untuk memberikan satu atau beberapa materi mata pembelajaran kepada seseorang atau masyarakat dengan waktu yang relatif singkat. Tujuan dari adanya penyelenggaraan kursus adalah untuk memperluas keikutsertaan masyarakat dalam pemerataan kesempatan belajar dan meningkatkan mutu warga masyarakat mealui pendidikan dan untuk meningkatkan proses belajar mengajar untuk mencapai daya guna dan hasil guna yang optimal.

Kursus memberikan kesempatan kepada setiap warga masyarakat untuk memperoleh pengetahuan praktis dan keterampilan fungsional sehingga dapat mendapatkan sumber penghasilan atau penghidupan tertentunya yang sesuai dengan bakat dan atau kemampuan amsing-masing individu.

\section{METODOLOGI}

Pendekatan yang digunakan dalam penelitian ini yaitu pendekatan kualitatif dengan metode deskriptif, yaitu berusaha memberikan informasi dengan sistematis dan cermat mengenai fakta-fakta aktual dan sifat populasi tertentu. Menurut Subana dan Sudrajat $(2005,89)$ penelitian deskriptif yaitu menuturkan dan menafsirkan data yang berkenaan dengan fakta, keadaaan, variable dan fenomena yang terjadi saat penelitian berlangsung dan menyajikannya secara apa adanya.

Nurul Zuliah (2009: 47) mengartikan Metode Penelitian deskriptif sebagai penelitian yang diarahkan untuk memberikan gambaran tentang gejala-gejala, fakta-fakta atau kejadian-kejadian secara sistematis dan akurat, mengenai sifat-sifat populasi atau daerah tertentu. Penggunaan metode deskriptif digunakan dalam rangka mendeskripsikan atau menggambarkan tentang persepsi para pengelola program terhadap tugas pokok penilik PNFI di Kabupaten Cirebon. Subjek kajian penelitian ini yaitu difukoskan bagi pengelola program PNFI dan penilik yang ada di kabupaten Cirebon wilayah Timur.

Teknik dan alat pengumpulan data meliputi wawancara, obervasi, studi dokumentasi, dan triangulasi. Selain teknik dan alat pengumpulan data, beberapa hal yang tidak kalah pentingnya adalah langkah-langkah penelitian. Menurut Arikunto (2010:25) dalam kegiatan penelitian sekurangkurangnya penelitian harus menyusun tahap persiapan, pelaksanaan, dan pelaporan. Untuk itu dalam penelitian ini dilakukan dalam empat tahap, yaitu: 1) tahap persiapan; 2) tahap pengumpulan data; 3 ) 
tahap analisis data; dan 4) tahap pelaporan. Selanjutnya analisis data yang digunakan yaitu reduksi data (data reduction), penyajian data (display data), dan kesimpulan (conclusion).

\section{HASIL DAN PEMBAHASAN}

1. Gambaran Tugas Pokok Penilik

Aspek-aspek yang akan dibahas dalam pelaksanaan tugas pokok dari Penilik PNFI yang mengacu pada Permenpan penilik yang terbaru No. 14 Tahun 2010 Tentang Jabatan Fungsional Penilik dan Angka Kreditnya. Dari acuan tersebut didapatkan bahwa tugas pokok dari Penilik PNFI adalah sebagai pengendali mutu program dimana dalam mengendalikan mutu program tersebut ada 7 penjabaran mengenai kegiatan atau sesuatu yang harus dilakukan oleh penilik dalam rangka meningkatkan mutu program, yaitu:

a. Perencanaan program pengendalian mutu PNFI;

b. Pengelolaan pemantauan program PNFI;

c. Pengelolaan penilaian PNFI;

d. Pengelolaan pembimbingan dan pembinaan kepada pendidik dan tenaga kependidikan pada satuan PNFI; dan

e. Penyusunan laporan hasil pengendalian mutu PNFI.

Sedangkan penjabaran dari evaluasi dampak program PNFI adalah sebagai berikut:

a. Penyusunan rancangan/desain evaluasi dampak program PNFI;

b. Penyusunan instrument evaluasi dampak program PNFI;

c. Pengelolaan dan penyusunan laporan hasil evaluasi dampak program PNFI; dan

d. Presentasi hasil evaluasi dampak program PNFI.

Penilik melakukan sebuah perencanaan terlebih dahulu ketika penilik akan melakukan sebuah kegiatan pemantauan. perencanaan ini begitu penting harus dilakukan oleh penilik, sesuai dengan apa yang diungkapkan oleh Kauffman (1972) bahwa: "Perencanaan adalah suatu proses menentukan tujuan atau sasaran yang hendak dicapai dan menetapkan jalan dan sumber yang dipelukan untuk mencapai tujuan itu secara efisien dan juga efektif".

Salah satu tugas penilik melaksanakan kegiatan bimbingan atau supervisi dan monitoring. Kegiatan supervisi atau bantuan yang dilakukan oleh penilik ini adalah dengan memberikan bantuan kepada para pengelola program berupa pemecahan berbagai permasalahan yang dihadapi oleh pengelola program, meskipun penilik pun terkadang membantu cara-cara untuk menyadari dan member pengertian tentang kebutuhan-kebutuhan dan masalah-masalah yang dihadapi warga belajar dan juga penilik memberikan cara-cara meningkatkan kualitas pembelajaran.

Ketika ada permasalahan yang sedang dihadapi oleh para warga belajar tidak hanya penilik saja yang harus mengetahuinya, yang lebih penting adalah pengelola program harus mengetahuinya. Dari permasalahan yang sedang dihadapi oleh para warga belajarnya, pengelola program pun harus bisa memberikan pemecahan terhadap masalah-masalah yang dihadapi warga belajar tersebut dan juga sebelum permasalahan program atau kelembagaan 
yang sedang dihadapi juga harus dipecahkan terlebih dahulu oleh pengelola program sendiri sebelum dipecahkan oleh penilik.

Selain sebagai seorang supervisor, penilik pun harus mempunyai kompetensi sebagai pengelola monitoring. Kegiatan moniroting merupakan aspek penting dalam kegiatan penilik untuk mengontrol program ataupun proses pembelajaran yang dilaksanakan oleh lembaga binaannya. Kegiatan monitoring dimaksudkan untuk mengetahui kecocokan dan ketepatan kegiatan yang dilaksanakan dengan rencana yang telah disusun.

Monitoring digunakan pula untuk memperbaiki kegiatan yang menyimpang dari rencana, mengoreksi penyalahgunaan aturan dan sumber-sumber, serta untuk mengupayakan agar tujuan dicapai seefektif dan seefisien mungkin. Hal ini juga sejalan dengan apa yng diungkapkan oleh UNESCO Regional Office for Education in Asia and The Pacific, dijelaskan bahwa monitoring adalah upaya yang dilakukan secara rutin untuk mengidentifikasi pengelolaan dari berbagai program sebagaimana telah diajdwalkan, dan kemajuan dalam mencapai tujuan program.

\section{Manfaat yang Dirasakan Pengelola Program}

Penilik melaksanakan tugasnya kepada lembaga yang menjadi binaannya dalam rangka pengendalian mutu program tentunya ada manfaat yang diperoleh dan bukan tanpa ada hasil yang berarti. Apa yang sudah dilaksanakan penilik tentunya ada manfaat yang didapatkan oleh pengelola program. dalam pengelolaan program pengendalian mutu, seorang penilik harus mempunyai kemampuan sebagai perencana program, sebagai seorang supervisi dan monitoring dan juga sebagai seorang evaluator.

Kegiatan pengendalian mutu program yang dilakukan oleh penilik dimulai dari perencanaan, pengelolaan penilaian sampai dengan evaluasi program. bahwasanya pengendalian mutu ini merupakan suatu kegiatan pengedalian yang ditujukan untuk menjamin mutu program dan memantau mutu kerja yang merupakan salah satu rancangan (titik awal) untuk mencapai tujuan yang telah ditetapkan sebelumnya.

Pengendalian mutu program ini juga merupakan kegiatan yang ditujukan untuk menjamin kualitas proses pembelajaran, jaringan kemitraan dan pelayanan informasi yang dilakukan oleh penilik, pengelola dan pengelola program sebagai indikator keberhasilan dari program yang dijalankan. Ketika suatu lembaga dikatakan mutu program yang dijalankan itu baik bisa dilihat dari sistem administrasi, sarana prasarana yang digunakan dalam kegiatan pembelajaran, dan juga dana yang digunakan ketika melaksanakan program dan dana yang digunakan pun tidak selamanya berasal dari pemerintah. Lembaga yang mutunya baik itu harus bisa mengelola atau melaksanakan program dengan tidak selalu mengandalkan dana yang disediakan oleh pemerintah, karena jika terlalu mengandalkan dana dari pemerintah maka ketika pemerintah tidak menyediakan dana program tersebut tidak akan berjalan.

Dalam melaksanakan kegiatan pengendalian mutu program sejalan dengan apa yang sudah diungkapkan dalam teori bahwa para pendidik diperlakukan sebagai seorang perencana, pendorong, pengarah, fasilitator, evaluator, motivator serta narasumber dalam memberikan

didikan, bimbingan, asuhan, pengajaran dan pelatihan bersifat dinamis. Dengan kata lain 
pengendalian mutu program ini merupakan suatu keharusan yang harus dipahami oleh semua pihak, karena pengendalian mutu akan berkaitan dengan kepuasan dari pengguna (stake holder).

Pengendalian mutu program ini juga diharapkan program yang sudah dilakukan oleh lembaga-lembaga pendidikan nonformal sesuai dengan standar pendidikan nasional sebagaimana yang diamanatkan dalam Undang-undang tentang Standar Nasional Pendidikan, dimana Standar Nasional Pendidikan ini menurut Undang-undang mencakup 8 standar yaitu standar isi, standar proses, standar pengelolaan pendidikan, standar sarana dan prasarana, standar pendidik dan tenaga kependidikan, standar pembiayaan, standar penilaian dan standar kompetensi lulusan.

Meskipun pada dasarnya kegiatan pengendalian mutu program dan evaluasi dampak sesuai dengan Permenpan No. 14 Tahun 2010 yang dilakukan oleh penilik ini belum terlaksana, akan tetapi pada tugasnya penilik setidaknya sudah mulai menyesuaikan dengan apa yang diharapkan dalam pengendalian mutu program yang mencakup tentang perencanaan program pengendalian mutu, pengelolaan pemantauan, penilaian, bimbingan dan pembinaan kepada pendidik dan tenaga kependidikan serta evaluasi dampak program.

Dalam pengendalian mutu program proses pembelajaran pun menjadi salah satu aspek penting yang dapat menunjang bahwa program itu dikatakan mutu atau kualitasnya bagus. Mutu proses belajar mengajar dapat terlihat ketika kurikulum yang dibuat oleh para pendidik dan tenaga kependidikan yang dibimbing dan dibina oleh penilik sesuai dengan apa yang diharapkan, serta pelayana dan juga pengembangan metode pembelajaran. Ketika pendidik atau narasumber memberikan pembelajaran dengan metode yang monoton maka otomatis para warga belajar akan jenuh dan lambat laun warga belajar akan menjadi malas belajar.

\section{KESIMPULAN}

Penilik ini merupakan salah satu tenaga kependidikan nonformal yang bertugas di lapangan untuk memberikan bimbingan, arahan bantuan dan evaluasi kepada para pelaksana program dalam kelembagaan pendidikan nonformal agar sesuai dengan yang diharapkan. Penilik sebagai petugas lapangan ternyata selain orang yang secara langsung berhubungan dengan sasaran program Pendidikan Luar Sekolah, juga sebagai penentu dalam mengimplementasikan dan memadukan keseluruhan program PNFI baik secara horizontal maupun vertikal. Di sisi lain mereka juga menjadi penyeimbang antara program yang datang dari atas dengan tuntutan kebutuhan yang ada di masyarakat itu sendiri.

Dalam melaksanakan tugasnya, pada umumnya penilik sudah dengan baik melaksanakan kegiatan pengendalian mutu program PNFI dan evaluasi dampak program PNFI meskipun ada beberapa kekurangan dari penilik dalam melaksanakan tugasnya dan juga penilik di Kabupaten Cirebon belum terbagi menjadi 3 penilik di setiap kecamatannya sesuai dengan apa yang ada di dalam peraturan yang terbaru.

Pengelola program PNFI sangat merasakan banyak sekali manfaat yang bisa diambil dari pelaksanaan tugas pokok penilik tersebut, dibuktikan dengan semakin membaiknya program-program yang dijalankan oleh para pengelola program, hal ini juga dibuktikan atau didukung dengan adanya akreditasi dari setiap lembaga pendidikan nonformal. Meskipun penilik sudah berusaha sebaik mungkin 
dalam menjalankan tugasnya, tentunya masih ada beberapa kekurangan yang dimiliki oleh penilik, sehingga pengelola mempunyai harapan kepada penilik demi perbaikan program agar menjadi lebih berkualitas.

\section{DAFTAR PUSTAKA}

Arikunto, S. (2010). Prosedur Penelitian Suatu Pendekatan Praktik. Jakarta: Rineka Cipta.

Kartiwa, M. (2005). Pengaruh Motivasi Kerja Penilik PLS di Kota Bandung. Skripsi PLS FIP UPI Bandung: tidak diterbitkan.

Kauffman, R.A. (1972). Educational System Planning. New Jersey: Prentice Hall, Inc.

Rahmat, A. (2011). analisis Kinerja Penlik PNF di Kabupaten Gorontalo: Jurnal Ilmiah Visi P2TK PAUDNI. Vol 6. No 1, Juni 2011: 82-92.

Sappaile, B.I. (2007). Kemampuan Penilik dalam Melaksanakan Tugas Pokok Ditinjau dari Keputusan Menpan No 15/KEP/MENPAN/3/2002: Jurnal Ilmiah Visi PTK-PNF. Vol 2. No 1, 2007: 64-69.

Sobur, Alex. (2003). Psikologi Umum. Bandung: Pustaka Setia.

Subana, M. dan Sudrajat (2005). Dasar-dasar Penelitian Ilmiah. Bandung: CV Pustaka Setia.

Suryadi, A. (2009). "Peningkatan Mutu dalam Perspektif Pemikiran Ekonomi Pendidikan". Bandung: tidak diterbitkan.

Undang-Undang Sistem Pendidikan Nasional No 20 Tahun 2003

Permenpan No 14 Tahun 2010 Tentang Jabatan Fungsional Penilik dan Angka Kreditnya 